\title{
Quality Enhancement of Black Soybean [Glycine max (L.) Merrill] Flour using Germination Technique
}

Neetu Dobhal, R.S. Raghuvanshi

10.18805/LR-4711

\begin{abstract}
Background: Black soybean [Glycine max (L.) Merrill] is grown on 5734 hectare area of Kumaon and Garhwal region of Uttarakhand state of India but consumed on a very limited scale. The bioavailability of nutrients in soybean is limited due to presence of antinutritional factors such as trypsin inhibitors, oligosaccharides and tannins etc. Literature still lacks in data related to nutritional and health enhancing properties of black soybean, therefore, the present study was undertaken to enhance the nutritional quality of black soybean using germination technique.

Methods: Two types of flour were developed from black soybean i.e. raw and 72-hours germinated flour which were analyzed for their proximate and mineral composition, antinutritional content, antioxidant activity, in-vitro protein digestibility, in-vitro iron bioavailability and dietary fibre content.

Result: The findings revealed that germination led to significant $(P \leq 0.05)$ increases in crude protein, crude fibre, total ash, calcium, iron, magnesium, zinc, in-vitro protein digestibility and total dietary fibre content with significant $(P \leq 0.05)$ reductions in phytates, tannins, oxalates, trypsin inhibitor and oligosaccharide content of black soybean flour. The study concluded that germination significantly enhanced the nutritional properties of black soybean by increasing the density and bioavailability of nutrients and reducing the anti nutrients, thereby making it safer for human consumption.
\end{abstract}

Key words: Anti-nutritional factors, Antioxidant activity, Black soybean, Germination.

\section{INTRODUCTION}

Legumes are widely grown throughout the world and their dietary and economic importance is globally recognized. Soybean [Glycine max (L.) Merrill] is a member of family Leguminosae and subfamily Papilionideae, native to Northeastern China and distributed in Asia. India is the Asia's second and World's fourth largest producer of soybean accounting for about $3.95 \%$ of global production (Agarwal, 2013).

Soybean, being an excellent source of nutrients, bioactive components and health promoting phytochemicals, is also known as 'wonder bean' and "a golden gift of nature to humanity". The protein content of soybean varies from $31-49 \%$ with the best amino acid profile amongst all plant proteins (FAO, 2012). Soybean is a rich source of essential fatty acids i.e. linoleic acid $(53 \%)$ and $\alpha$-linolenic acid $(8 \%)$, with $\omega-6 / \omega-3$ ratio of 6 $7: 1$, which is in the range of ideal ratio $(5-10: 1)$ required by human body (ICMR, 2010). Processing viz boiling, cooking and sprouting of legumes greatly influence nutritional quality by increasing bioavailability of nutrients as well as enhancing digestibility and utilization of nutrients.

Black soybean, locally known as Bhatt/Bhatmash, one major crop of Uttarakhand state, is grown in 5734 hectare area with the yield and productivity of $5636 \mathrm{t}$ and $9.82 \mathrm{q} / \mathrm{ha}$, respectively. Besides its nutraceutical potential, this crop plays a vital role in ensuring nutritional and livelihood security of rural population of hills. It is considered as a "treasure house of nutritional and medicinal properties".

Research work related to nutritional composition has been reported on the yellow and white varieties of soybean but scanty information is available for black soybean.
Department of Foods and Nutrition, College of Home Science, Govind Ballabh Pant University of Agriculture and Technology, Pantnagar-263 153, Uttarakhand, India.

Corresponding Author: Neetu Dobhal, Department of Foods and Nutrition, College of Home Science, Govind Ballabh Pant University of Agriculture and Technology, Pantnagar-263 153, Uttarakhand, India. Email: nishudhnew@gmail.com

How to cite this article: Dobhal, N. and Raghuvanshi, R.S. (2022). Quality Enhancement of Black Soybean [Glycine max (L.) Merrill] Flour using Germination Technique. Legume Research. DOI: $10.18805 / L R-4711$.

Submitted: 23-06-2021 Accepted: 03-01-2022 Online: 03-03-2022

Therefore, the present investigation aimed on assessing the effect of germination on nutritional quality of VL-63 variety of black soybean.

\section{MATERIALS AND METHODS} Locale and duration of the study

The present study was conducted in Department of Foods and Nutrition, College of Home Science, G.B. Pant University of Agriculture and Technology, Pantnagar, Udham Singh Nagar, Uttarakhand in the year 2018.

\section{Material procurement}

Black soybean (VL-63 variety) was procured from Tarai Development Corporation (TDC), Haldi, U.S. Nagar. The seeds of black soybean were cleaned manually to remove foreign materials (dust, dirt, grit and other impurities), broken and immature soybeans. 


\section{Germination}

Black soybean seeds were overnight soaked in potable water (seed to water ratio of 1:5) at room temperature. Soaked water was drained and seeds were tied in a muslin cloth and kept for germination for 72-hours in incubator at $32 \pm^{\circ} \mathrm{C}$. Water was sprinkled once daily to provide moisture during germination. Germinated seeds were oven dried at $65 \pm 2^{\circ} \mathrm{C}$ till completely dried. Dried seeds were ground using flour mill, followed by sieving through 60 mesh sieve. Flour was kept in airtight containers at room temperature for further analysis. Raw black soybean (non-germinated) flour was used as control.

\section{Proximate composition analysis}

Flour samples obtained from raw and germinated black soybean seeds were estimated for their moisture, crude protein, crude fibre, ash and crude fat contents (AOAC, 1995). All the experiments under study were carried out in triplicates in order to reduce the variability among the results and to establish reliability of the results. Crude fat was estimated in Sox Plus SPS 20 (Pelican Bio Innovations Pvt. Ltd.) and the crude protein was estimated by Kjeldahl method. Carbohydrate content was determined by difference. Physiological energy was calculated in kcal per $100 \mathrm{~g}$ using the formula:

$$
(9 \times \% \text { fat })+(4 \times \% \text { protein })+(4 \times \% \text { carbohydrate })
$$

\section{Minerals estimation}

For estimation of calcium, magnesium, zinc, copper and iron, flour samples were digested with a mixture of nitric acid, perchloric acid and sulphuric acid in the ratio of 3:2:1 (v/v) (Raghuramulu et al., 2003). After complete digestion, samples were cooled at room temperature and volumes made up to $100 \mathrm{ml}$. Minerals were analyzed by Atomic Absorption Spectrophotometry.

\section{Antinutritional factors}

The antinutritional factors analyzed in the present research included trypsin inhibitor activity, tannins, phytate, oxalate and oligosaccharids. Total tannin, phytate and oxalates were estimated using methods of AOAC (1970), Wheeler and Ferrel (1971) and Baker (1952), respectively. Trypsin inhibitor activity was determined by the method developed by Liu and Markakis (1989a) using benzoyl-DL-arginine-p-nitroanilide (BAPNA) as substrate. Oligosaccharides viz raffinose and stachyose were estimated using procedure given by Tanaka et al. (1975), in which, an aqueous alcoholic extract of legume seeds was prepared and then chromatographed by paper chromatography for the analysis of its sugar content. Their quantities were determined colorimetrically after elution from a cut out spot on a paper chromatogram. The amounts of raffinose and stachyose were determined using thiobarbituric acid reaction (Percheron, 1962).

DPPH radical scavenging activity and total antioxidant capacity (TAC)

DPPH radical scavenging activity of black soybean flours was estimated by the 1, 1-diphenyl-2-picryl-hydrazyl (DPPH) method of Brand-William et al. (1995). Total antioxidant capacity (TAC) was estimated in terms of milligram of trolox equivalent/100 g sample.

\section{In-vitro protein digestibility}

The protein availability was assessed in terms of in-vitro protein digestibility using the procedure given by Akeson and Stahman (1964). The nitrogen content of the black soybean sample and the undigested residue were determined by the micro-kjeldahl method (AOAC, 1995). The digested protein of the sample was calculated by subtracting residual protein from total protein of the sample and protein digestibility was calculated using the formula:

$$
\text { Protein digestibility }(\%)=\frac{\text { Digested protein }}{\text { Total protein }} \times 100
$$

\section{In-vitro iron bioavailability}

In-vitro iron bioavailability of raw and germinated black soybean flours was determined by the method given by Rao and Prabhavati (1978), which is based on the release of the ionisable iron from food subjected to treatment with pepsin$\mathrm{HCl}$ at $\mathrm{pH} 1.35$ and subsequent adjustment of $\mathrm{pH}$ to 7.5 stimulating conditions prevailing in stomach and intestine, respectively.

\section{Dietary fibre}

Total dietary fibre content was estimated using method of Asp et al. (1983) which included gelatinization and enzymatic digestion of flour followed by filtration, washing and titrimetric estimation of dietary fibre, respectively.

\section{Statistical analysis}

Experiments were carried out in triplicates. All the quantitative data was computed in terms of mean and standard deviation. Data were subjected to one-way ANOVA (F-test) to determine significance of difference among raw and germinated black soybean flours with respect to different attributes. Critical difference was calculated at $5 \%$ level of significance (Snedecor and Cochran, 1967).

\section{RESULTS AND DISCUSSION}

\section{Proximate composition}

The findings showed the germ length of $1.08 \pm 0.05 \mathrm{~cm}$, $2.63 \pm 0.94 \mathrm{~cm}$ and $4.14 \pm 0.37 \mathrm{~cm}$, on completion of 24,48 and 72 hours of germination, respectively. Effect of germination on proximate composition of black soybean flour is shown in Table 1. The moisture content of raw black soybean increased significantly $(p \leq 0.05)$ after germination $(19.25 \%)$. As germination proceeded, legumes took up water from the surrounding for getting ready to the commencing metabolic process. After penetration of water through seed coat, seed swelling started and initiated sprouting. Dobhal and Raghuvanshi (2018) showed that higher hydration capacity permits the black soybean seeds to absorb more amount of water leading to high moisture content. 
Quality Enhancement of Black Soybean Glycine max (L.) Merrill Flour using Germination Technique

Table 1: Proximate composition of raw and germinated black soybean (dry wt. basis).

\begin{tabular}{lrrr}
\hline Parameter & \multicolumn{1}{c}{ Raw } & Germinated & CD at 5\% \\
\hline Crude fat (\%) & $19.25 \pm 0.82$ & $17.00 \pm 1.71$ & 1.91 \\
Crude protein (\%) & $43.62 \pm 1.04$ & $47.27 \pm 0.29$ & 1.27 \\
Total ash (\%) & $5.96 \pm 0.45$ & $7.40 \pm 0.53$ & 0.80 \\
Crude fibre (\%) & $5.28 \pm 0.17$ & $8.23 \pm 0.09$ & 0.31 \\
Carbohydrate by difference (\%) & $25.89 \pm 0.26$ & $20.10 \pm 2.00$ & 1.34 \\
Physiological energy (kcal) & $451.29 \pm 3.94$ & $422.48 \pm 9.01$ & 1.48 \\
\hline
\end{tabular}

Table 2: Mineral composition of raw and germinated black soybean (mg/100 g) (dry wt. basis).

\begin{tabular}{lrrr}
\hline Mineral & \multicolumn{1}{c}{ Raw } & Germinated & CD at $5 \%$ \\
\hline Calcium & $268.79 \pm 1.72$ & $336.19 \pm 1.28$ & 1.34 \\
Iron & $9.84 \pm 1.56$ & $15.58 \pm 1.12$ & 1.25 \\
Magnesium & $264.54 \pm 1.36$ & $290.42 \pm 2.97$ & 1.05 \\
Zinc & $4.79 \pm 0.24$ & $5.42 \pm 0.10$ & 0.28 \\
Copper & $2.35 \pm 0.03$ & $2.51 \pm 0.13$ & 0.21 \\
\hline
\end{tabular}

As evident from Table 1, germination led to significant $(p \leq 0.05)$ increase in crude protein by $8.37 \%$. The apparent increase in crude protein can be attributed to utilization of carbohydrates as energy source for developing sprouts and also due to the release of free amino acids after enzymatic hydrolysis for the synthesis of new protein. Similar findings on increase in protein content after germination have been reported for various legumes by Warle et al. (2015). Total ash provides a measure of the total amount of minerals within a food. The findings of the present study showed that germination led to significant $(p \leq 0.05)$ increase of $24.17 \%$ in total ash content of black soybean flour.

Crude fibre is the indigestible substance obtained as a residue of a precisely defined digestion procedure. It consists of substances from vegetable cell wall. A significant $(p \leq 0.05)$ increase of $55.87 \%$ in crude fibre content of black soybean was observed due to germination. The crude fat content of germinated black soybean decreased significantly $(p \leq 0.05)$ by $11.69 \%$, respectively. The decrease in the crude fat content could be due to the fact that the pericarp and seed coat of black soybean which are mainly composed of the fatty component got affected with processing. It might also be attributed to the depletion of stored fat which contributes to the catabolic activities of the seeds during germination.

Table 1 indicates that in the present study, germination significantly $(p \leq 0.05)$ decreased the total carbohydrate content of black soybean flour from 25.89 to $20.10 \%$. The decrease in carbohydrate content may be due to the active respiration process during germination, increasing the $\beta$ amylase activity and thereby leading to the breakdown of number of carbohydrate molecules in order to allow increased protein synthesis. Physiological energy of black soybean flours in the present study ranged from 422 (germinated) to $451 \mathrm{kcal} / 100 \mathrm{~g}$ (raw), which is higher than the value reported by Longvah et al. (2017) for yellow soybean.

\section{Mineral composition}

Mineral composition of raw and germinated black soybean is shown in Table 2. As the table depicts, calcium, iron, magnesium and zinc content of germinated black soybean were significantly $(p \leq 0.05)$ higher than its raw counterpart. Germination significantly $(p \leq 0.05)$ increased the calcium, iron, magnesium and zinc content of black soybean flour by $47.14,58.33,9.78$ and $13.15 \%$, respectively. This may be attributed to the reduced content of antinutritional factors viz phytate and oxalate content in the germinated black soybean flour over its raw counterpart. Phytates and oxalates form insoluble complexes with divalent cations like calcium, iron, zinc, magnesium, thereby reducing their bioavailability. Kayembe and Rensburg (2013) reported that the loss of divalent metals was low during germination due to their binding to protein and the formation of a phytate-cationprotein complex. A non-significant $(p \leq 0.05)$ increase in copper content was found after germination of black soybean flour.

\section{Antinutritional factors}

Antinutritional factors are the substances generated in natural food substances by the normal metabolism of species by different mechanisms which exert effects contrary to optimum nutrition. In the present study, germination led to significant reduction in phytate $(39 \%)$, tannins $(55.3 \%)$, trypsin inhibitor activity $(28.7 \%)$ and oxalate $(50 \%)$ content of raw black soybean (Fig 1). Uppal and Bains (2012) observed $43.19 \%$ decrease in phytic acid in cowpea after germination for 24 hours. The reason might be the increased activity of phytase enzyme during germination which leads to the hydrolysis of phytate phosphorous and decrease in phytic acid content, hence releasing the soluble proteins and minerals. Reduction in oxalate content with germination might be the activation of oxalate oxidase enzyme during processing which breaks down oxalic acid into carbon dioxide and hydrogen peroxide consequently releasing calcium.

Tannins are the condensed polyphenolic compounds that bind with iron irreversibly and interfere with the iron absorption. These are also known to bind proteins and reduce their availability. Kayembe and Rensburg (2013) reported decrease of $22.49 \%$ in tannin content of yellow soybean with germination. Ramakrishna et al. (2006) showed the reduction in the trypsin inhibitor activity of various legumes in the range of $17-54.8 \%$ with 72 -hours germination. 
The reduction in trypsin inhibitor activity of germinated black soybean flour in the present study might be attributed to the proteolytic activity of enzymes i.e. trypsin and chymotrypsin, which got activated during germination.

Oligosaccharides i.e. raffinose, stachyose and verbascose are thought be the major producers of flatulence in soybean leading to its reduced utilization (Aremu et al., 2006). Germination led to reduction in raffinose and stachyose content of black soybean flour by 42.18 and $51.78 \%$, respectively. The decrease in the level of oligosaccharides during germination might be attributed to hydrolysis of these into disaccharides and monos accharides. El-Adawy et al. (2003) showed significant reduction in raffinose and stachyose content of peas, mung bean and lentil with germination of 72 hours. Chandrashekhraiah (2013) showed similar findings with respect to decrease in antinutritional factors with germination.

\section{In-vitro protein digestibility}

Combination of traditional food processing and preparation practices can increase the bioavailability of protein and micronutrients. In present study, germination led to significant increase $(p \leq 0.05)$ of $26.45 \%$ in the in-vitro protein digestibility of black soybean flour (Fig 2). This may be attributed to the mobilization of seed proteins and catalysis of anti-metabolites like protease inhibitors, phytic acid, polyphenols and trypsin inhibitors leading to increased availability of protein.

\section{In-vitro iron availability}

The findings on the in-vitro iron bioavailability of black soybean flours in the present study showed a range from 8.64 (raw) to $44.65 \%$ (germinated). Germination led to significant $(p \leq 0.05)$ increase in the in-vitro iron bioavailability (Fig 2). This finding is in accordance to the finding of Barakoti and Bains (2007), who suggested that all the processing subjected to mung bean (soaking, germination, cooking, fermentation and dehulling) resulted in an increase in the in-vitro iron bioavailability; the maximum bioavailability was in germinated, followed by fermented and raw mung bean. The reason might be the increased activity of phytase enzyme during germination leading to increased

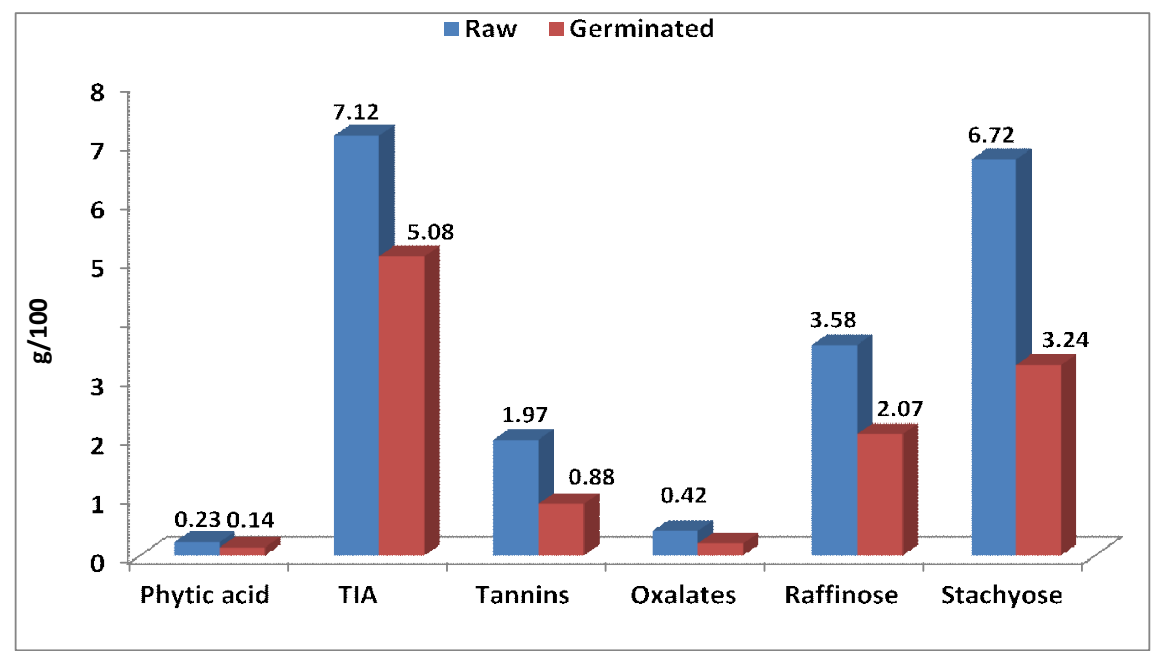

Fig 1: Effect of germination on antinutritional content of black soybean flour (dry wt. basis).

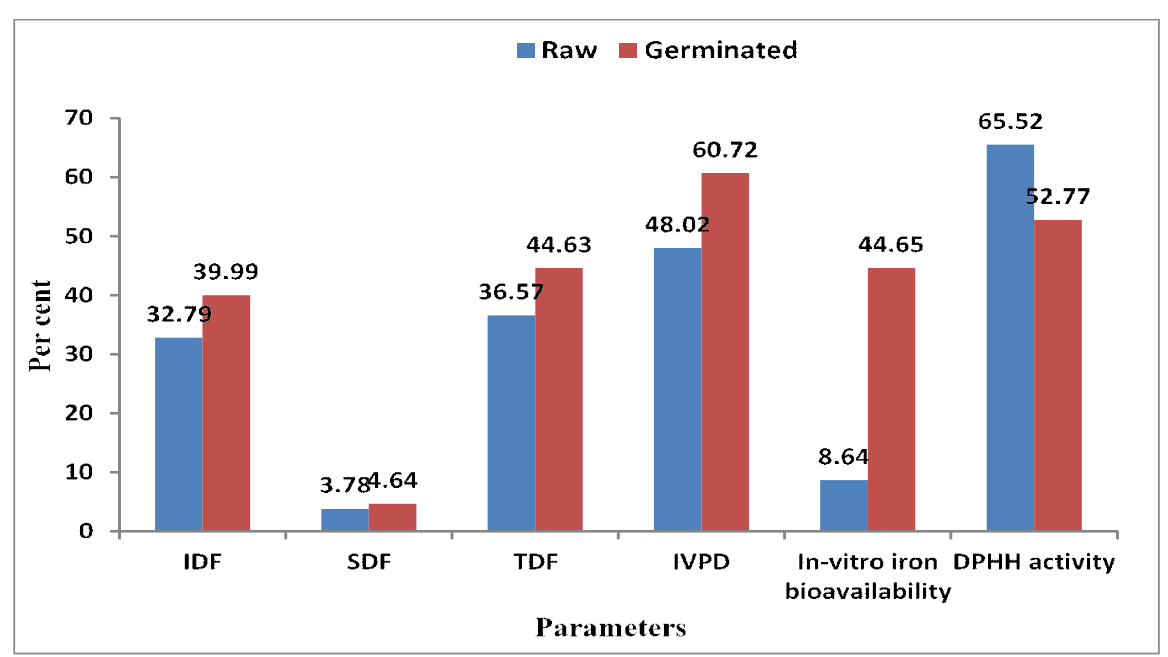

Fig 2: Effect of germination on other dietary parameters and DPPH activity of black soybean (dry wt. basis). 
catabolism of phytic acid and thereby increasing the invitro availability of divalent minerals like calcium, iron, zinc and magnesium.

\section{Dietary fibre}

Dietary fibre includes oligosaccharides, polysaccharides and lignin etc. The diets with high fibre content such as cereals, millets, fruits and vegetables exert positive effect on health. The findings of present study showed insoluble dietary fibre (IDF), soluble dietary fibre (SDF) and total dietary fibre (TDF) content of raw black soybean flour as $32.79,3.78$ and $36.57 \%$ and of germinated black soybean flour as 39.99 , 4.64 and $44.63 \%$, respectively (Fig 2). This implies that germinated black soybean flour had significantly $(p \leq 0.05)$ higher values for dietary fibre content than the raw flour. Pisarikova and Zraly (2010) reported the TDF content of yellow soybean as 35.5 per cent.

\section{DPPH radical scavenging activity and total antioxidant activity (TAC)}

Black soybeans have been found to contain high contents of phytochemicals including a-tocopherol, isoflavones, flavonoids and anthocyanins, possessing biological activity (Kumar et al., 2010). Fig 2 shows that germination led to significant $(p \leq 0.05)$ reduction of 19.46 and $22.64 \%$ in DPPH activity and TAC of raw black soybean flour, respectively. The reason might be attributed to the leakage of antioxidant components in soaked water. Xu and Chang (2008c) revealed that decrease in the overall antioxidant properties of processed legumes could be related to several types of factors including oxidative reaction, leaching of water soluble antioxidant compositions and solid losses during treatments.

\section{CONCLUSION}

The present research revealed the effect of germination on the nutritional and antinutritional properties of black soybean flour. Protein content increased while the fat content significantly reduced due to germination. The results showed the significant improvement in mineral content along with significant decrease in phytic acid, trypsin inhibitor activity, tannins, oxalate and oligosaccharide content of the black soybean flour. Significant increase in IVPD, in-vitro iron bioavailability and total dietary fibre was observed with germination technique. It is concluded that germination is a simple, effective and an inexpensive way of improving the nutritional profile and nutrient density of black soybean and its flour, which can be incorporated in various types of infant and young children's foods.

\section{Conflict of interest: None.}

\section{REFERENCES}

Agarwal, D.K., Billore, S.D., Sharma, A.N., Dupare, B.U. and Srivastava, S.K. (2013). Soybean: Introduction, improvement and utilization in India-Problems and prospects. Agricultural Research. 2(4): 293-300.
Akeson, W.R. and Stahmann, M.A. (1964). A pepsin-pancreatin digest index of protein quality evaluation. Journal of Nutrition. 83: 257-261.

AOAC. (1970). Official methods of analysis of the Association of Official Analytical Chemists. $11^{\text {th }}$ ed. Ed. By W. Horwitz. Washington D.C.

AOAC. (1995). Official Methods of Analysis of the Association of Official Analytical Chemists. $12^{\text {th }}$ ed. Ed. by Horwitz W. Washingt on D.C.

Aremu, M.O., Olaofe, O. and Akintayo, E.T. (2006). Mineral and amino acid composition of bambara ground nut (Vigna subterranean) and Kerstings groundnut (Kerstingiellageocarpa) flour. International Journal of Chemistry.16:57-64.

Asp, N.G., Johansson, C.G., Hallmer, H. and Siljestrom, M. (1983). Rapid enzymatic assay of insoluble and soluble dietary fiber. Journal of Agricultural and Food Chemistry. 31(3): 476-482.

Baker, C.J.L. (1952). The determination of oxalates in fresh plant materials. Analyst. 77: 340-344.

Barakoti, L. and Bains, K. (2007). Effect of house hold processing on the in vitro bioavailability of iron in mung bean (Vigna radiata). Food and Nutrition Bulletin. 28(1):18-22.

Brand-Williams, Cuvelier, M.E. and Berset, C. (1995). Use of a free radical method to evaluate antioxidant activity. LWTFood Science and Technology. 28(1): 25-30.

Chandrashekharaiah, K. (2013). Storage proteins and trypsin inhibitors of an underutilized legume, Mucuna: variability and their stability during germination. American Journal of Plant Sciences. 4(4): 910-916.

Dobhal, N. and Raghuvanshi, R.S. (2018). Physical characteristics and effect of germination on functional properties of black soybean (Glycine max). Asian Journal of Dairy and Food Research. 37(1): 56-60.

El-Adawy, T.A., Rahma, E.H., Bedawey, A.A. and Beltagy, A.E. (2003). Nutritional potential and functional properties of germinated mung bean, pea and lentil seeds. Plant Foods for Human Nutrition. 58: 1-13.

FAO. (2012). FAO STAT database. Food and Agriculture Organization of the United Nation, Rome, Italy.

ICMR. (2010). Nutrient requirements and recommended dietary allowances for Indians. A report of the expert group of the ICMR. pp. 139.

Kayembe, N.C. and Rensburg, C.J.V. (2013). Germination as a processing technique for soybeans in small-scale farming. South African Journal of Animal Science. 43(2): 167-173.

Kumar,V., Rani, A., Dixit, A.K., Pratap, D. and Bhatnagar, D. (2010). A comparative assessment of total phenolic content, ferric reducing-anti oxidative power, free radical-scavenging activity, vitamin $\mathrm{C}$ and isoflavones content in soybean with varying seed coat colour. Food Research International. 43: 323-328.

Liu, K. and Markakis, P. (1989a). Trypsin inhibition assay as related to limited hydrolysis of inhibitors. Analytical Biochemistry. 178(1): 159-165.

Longvah, T., Ananthan, R., Bhaskarachary, K. and Venkaiah, K. (2017). Indian food composition tables. National Institute of Nutrition. pp. 578. 
Quality Enhancement of Black Soybean Glycine max (L.) Merrill Flour using Germination Technique

Percheron, F. (1962). Colorimetric determination of fructose and fructo furanosides by the thiobarbituric acid reaction. Comptes Rendus. 255: 2521.

Pisarikova, B. and Zraly,Z. (2010). Dietary Fibre Content in Lupine (Lupinus albus L.) and Soya (Glycine max L.) Seeds. Acta Veterinaria Brunensis. 79: 211-216.

Raghuramulu, N., Nari, K.M. and Kalyanasundaram, S. (2003). A Manual of Laboratory Techniques. Second edition. National Institute of Nutrition, ICMR, Hyderabad. pp. 421.

Ramakrishna, V., Rani, P.J. and Rao, P.R. (2006). Anti-nutritional factors during germination in Indian bean (Dolichos lablab L.) seeds. World Journal of Dairy and Food Sciences. 1(1) :6-11.

Rao, B.S. and Prabhavati, T. (1978). An in-vitro method for predicting the bioavailability of iron from foods. American Journal of Clinical Nutrition. 61(2): 169-175.

Snedecor, G.W. and Cochran, W.G. (1967). Statistical Methods. $6^{\text {th }}$ edn. Calcutta: Oxford and IBH Publishing Co. pp. 593.
Tanaka, M., Thananunkul, D., Lee, T.C. and Chichester, C.O. (1975). A simplified method for the quantitative determination of sucrose, raffinose and stachyose in legume seeds. Journal of Food Science and Technology. 40: 1087-1088.

Uppal, V. and Bains, K. (2012). Effect of germination periods and hydrothermal treatments on in-vitro protein and starch digestibility of germinated legumes. Journal of Food Science and Technology. 49(2): 184-191.

Warle, B.M., Riar, C.S., Gaikwad, S.S. and Mane, V.A. (2015). Effect of germination on nutritional quality of soybean (Glycine max). IOSR Journal of Environmental Science, Toxicology and Food Technology. 9(4): 13-16.

Wheeler, E.L. and Ferrel, R.E. (1971). A method for phytic acid determination in wheat and wheat fractions. Cereal Chemistry. 48: 312-320.

$\mathrm{Xu}$, B. and Chang, S. (2008c). Effect of soaking, boiling and steaming on total phenolic content and antioxidant activities of cool season food legumes. Food Chemistry. 110: 1-13. 